\title{
Field suppression of Fusarium wilt and microbial population Shifts in tomato rhizosphere following soil treatment with two selected endophytic bacteria
}

\section{Rania Aydi Ben Abdallah *, Hayfa Jabnoun-Khiareddine, Ahlem Nefzi, Fakher Ayed, Mejda Daami-Remadi}

Regional Research Centre on Horticulture and Organic Agriculture, University of Sousse, Chott-Mariem, Tunisia

\section{Article Info}

Received : 01.10 .2018

Accepted : 16.04.2019

\begin{abstract}
Two endophytic bacteria, Bacillus subtilis SV41 (KR818071) and B. amyloliquefaciens subsp. plantarum SV65 (KR818073), were assessed under field conditions for their capacity to control tomato Fusarium wilt in tomato and their effects on soil microbial activity. Six months after planting, Fusarium wilt severity, estimated through the vascular browning extent in tomato stems, was significantly reduced by 82.3 and $88.2 \%$ compared to control following bacterial treatments. The frequency of F.oxysporum reisolation from roots, collars and stems was also significantly lowered in treated plants compared to controls. These effects were associated with a significant improvement, by 10.6 to $16.3 \%$ over control, in plant height and root fresh weight and an increase in fruit production by $8.4-12.5 \%$. As for microbial activity, $F$. oxysporum population in the rhizosphere of tomato plants treated with B. subtilis SV41 and B. amyloliquefaciens subsp. plantarum SV65 was reduced by 87.5-91.7\%compared to the initial soil (sampled before planting) and by $88.4-92.3 \%$ relative to the rhizospheric soil of untreated plants (control soil). A significant enhancement in the total culturable bacterial community was also noted in the rhizosphere of tomato plants treated with both strains compared to initial and control soils where a significant enrichment in Pseudomonas and actinobacteria community was recorded.
\end{abstract}

Keywords: Endophytic bacteria, Fusarium wilt, growth-promoting, microbial community, soil, tomato.

(C) 2019 Federation of Eurasian Soil Science Societies. All rights reserved

\section{Introduction}

Plants are naturally associated with microbes in various ways (Vijayabharathi et al., 2016). To face biotic and abiotic stresses, plants interact with different members of soil biodiversity and especially microbial community. These relations involve positive and negative feedbacks between soil microbial agents, plants, and their chemical environment (Meena and Meena, 2017). Agriculturally important microorganisms can affect the efficiency of nutrient availability to grown plants and soil biodiversity, and can also regulate the interactions between plants and pathogenic microflora (Zeilinager et al., 2016). Interactions among plants and microbes can influence soil physiochemical, biochemical and microbiological properties (Dubey et al., 2016). In fact, beneficial microbial communities or microbial inoculants can offer various positive services for plants and soils including plant growth-promotion, nutrient efficiency, bioremediation, and suppression of bio-aggressors. A profound understanding of the environmental factors influencing the viability and performance of these microbial inoculants is essential of their large-scale use in sustainable agriculture production systems (Meena and Meena, 2017).

\footnotetext{
${ }^{*}$ Corresponding author.

UR13AGR09-Integrated Horticultural Production in the Tunisian Centre-East, Regional Research Centre on Horticulture and Organic Agriculture, University of Sousse, 4042, Chott-Mariem, Tunisia

Tel.: +21696325412

E-mail address: raniaaydi@yahoo.fr

e-ISSN: $2147-4249$ DOI: $10.18393 /$ ejss.556780
} 
Due to the increased need to reduce use of chemical fertilizers and pesticides, for sustainable agriculture and environment protection, there was a growing interest in searching for beneficial microorganisms (Figueiredo et al., 2016). Among the explored microorganisms, bacteria occurring in the rhizosphere soil, rhizoplane, and/or the internal plant tissues were widely used (Hallmann et al., 1997). Their beneficial effects include, among others, efficient systems for uptake and catabolism of organic compounds present in root exudates (Barraquio et al., 1997). Several bacteria may also help to derive maximum benefits from root exudates through their capacity to attach to root surface (rhizoplane) (Compant et al., 2005). Endophytic bacteria are able to grow inside plant tissues and to protect them from biotic and biotic stresses (Sharma and Nowak, 1998). They can stimulate plant growth via direct and/or indirect mechanisms. Directly, they act by providing essential nutrients, producing phytohormones and growth regulators, or by regulating phytohormone levels. Indirect plant growth promotion (PGP) may be achieved by suppressing pathogens and/or inactivating pollutants responsible for plant growth inhibition (Vijayabharathi et al., 2016).

Beneficial agents may adversely affect population, density, dynamics and metabolic activities of soilborne pathogens through the production of hydrolytic enzymes and antimicrobial secondary metabolites and/or through the competition for nutrients (Swarupa et al., 2016). Several microbial agents such as Trichoderma and Bacillus are able to suppress fungal inoculum in soils by producing antibiotics (Larkin and Tavantzis, 2013; Bernard et al., 2014).

The soil microbial community is thought to be responsible for biological processes that are necessary for maintaining a healthy soil and suppressing plant diseases (Mazzola, 2004). The biocontrol of soilborne diseases can be achieved by manipulating the rhizosphere microflora in favor of beneficial microorganisms acting directly against soil pathogens (Yang et al., 2001). There is a considerable interest in monitoring changes in activity and composition of soil microbial communities following the application of microbial inoculants. In fact, beneficial bacteria or fungi such as Trichoderma, Hypoxylon, Tritirachium, Paenibacillus, Bacillus, Haliangium and Streptomyces were more abundant in biologically treated soils as compared to control whereas Fusarium inoculum was markedly decreased (Qiu et al., 2012).

Two endophytic bacteria B. subtilis SV41 and B. amyloliquefaciens subsp. plantarum SV65 originally recovered from Datura metel and Solanum nigrum, respectively, were tested in this study under field conditions. They were previously (pot experiment) selected based on their ability to suppress Fusarium wilt and to promote tomato growth using their whole cells or their cell-free culture filtrates.

This study aimed to check, under field conditions, the ability of B. subtilis SV41 and B. amyloliquefaciens subsp. plantarum SV65 to enhance growth and production of tomato plants growing in soils naturally infested with Fusarium oxysporum f. sp. lycopersici (FOL) and to suppress wilt severity. Their subsequent effects on pathogen inoculum and soil microbial community were also investigated.

\section{Material and Methods}

\section{Plant material}

Tomato cv. Sahel was used in this study. This cultivar is known to be resistant to FOL races 1 and 2 and susceptible to race 3 (Syngenta, 2015). Seedlings were grown under greenhouse conditions $(16 \mathrm{~h}$ photoperiod, $60-70 \%$ relative humidity and $20-30^{\circ} \mathrm{C}$ air temperature $)$ in alveolus plates $(3 \times 3 \mathrm{~cm})$ filled with sterilized peat ${ }^{\circledR}$ (Floragard Vertriebs GmbH für gartenbau, Oldenburg) . They were watered regularly until reaching the two-true-leaf growth stage. Seedlings with approximately similar heights were used in all trials.

\section{Bacterial material}

Two endophytic bacterial strains namely Bacillus subtilis SV41 (Accession number KR818071) and Bacillus amyloliquefaciens subsp. plantarum SV65 (KR818073), originally recovered from the internal stem tissues of Datura metel and Solanum nigrum, respectively, were used in the current investigation.

Isolation procedure, characterization and identification using 16S rDNA sequencing genes were previously described in Aydi Ben Abdallah et al. (2015). These two strains were previously selected based on their higher efficiency, when used as cell suspensions or cell-free culture filtrates, in suppressing Fusarium wilt disease on tomato plants inoculated with FOL. Indeed, both Bacillus strains were harbor chitinase gene in their genome and B. amyloliquefaciens subsp. plantarum SV65 was able to produce the lipopetide antibiotic, fengycin $D$, which was detected in its genome. Also, the plant defense genes such as PR1, acidic PR3 and lipoxygenase $(L O X D)$ were expressed in tomato plants inoculated or not with FOL and treated with $B$. amyloliquefaciens subsp. plantarum SV65 (Aydi Ben Abdallah et al., 2017). Furthermore, the plant growthpromoting traits such as the production of indole-3-acetic acid, siderophores and organic acids in root exudates and the phosphate solubilization ability were recorded on both selected strains (unpublished data). Their plant growth-promoting properties and antagonististic mechanisms are detailed in Table 1. 
Table 1. Plant growth-promoting (PGP) traits, antagonistic and inducing systemic resistance (ISR) properties of Bacillus subtilis SV41 and Bacillus amyloliquefaciens subsp. plantarum SV65 recovered from Datura metel and Solanum nigrum stems, respectively.

\begin{tabular}{|c|c|c|c|c|c|c|c|c|c|c|c|c|}
\hline \multirow{2}{*}{ Strain } & \multicolumn{4}{|c|}{$\begin{array}{c}\text { PGP traits } \\
\text { (Unpublished data) }\end{array}$} & \multicolumn{8}{|c|}{$\begin{array}{l}\text { Antifungal and ISR properties } \\
\text { (Aydi Ben Abdallah et al., 2017) }\end{array}$} \\
\hline & $\sum_{\leq}^{\frac{\pi}{4}}$ & $\begin{array}{l}0 \\
\text { के } \\
\frac{1}{2}\end{array}$ & 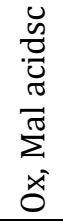 & 莕 & $\begin{array}{l}\mathscr{U} \\
0 \\
2\end{array}$ & 莺 & 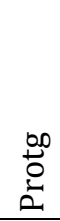 & 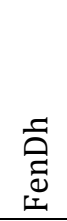 & 芯 & 离 & 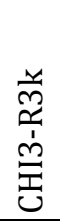 & $\overrightarrow{\nexists z}$ \\
\hline B. subtilis SV41 & + & - & + & + & + & + & + & - & + & - & - & - \\
\hline B. amyloliquefaciens subsp. plantarum SV65 & + & + & + & + & + & + & + & + & + & + & + & + \\
\hline
\end{tabular}

a IAA: Indole-3-acetic acid production after $48 \mathrm{~h}$ of incubation at $28 \pm 2^{\circ} \mathrm{C}$ in Luria-Broth medium; +: Production of IAA.

b Phosphatase activity: Tested on Pikovskaya agar medium and incubated at $28 \pm 2^{\circ} \mathrm{C}$ for 7 days; +: Presence of clear zone, -: Absence of clear zone.

c Organic acids (oxalic and malic acids) production detected in root exudates which are collected after 14 days from tomato plants cultivated in Hoagland solution (50 \%).

d Siderophore production: Tested on Chrome Azurol Sulphonate (CAS) agar medium and incubated at $28 \pm 2{ }^{\circ} \mathrm{C}$ for 5 days; +:

Presence of zone of siderophore activity (yellow color).

e Pectinolytic activity:Tested on pectin-agar ( $0.5 \%$ w v- 1$)$ medium and incubated at $28 \pm 2{ }^{\circ} \mathrm{C}$ for $48 \mathrm{~h}$; +: Presence of clear zone. The Polygalacturonic acid was measured at $540 \mathrm{~nm}$.

f Chitinase activity:Tested on chitin-agar ( $0.5 \% \mathrm{w}$ v-1) medium and incubated at $28 \pm 2^{\circ} \mathrm{C}$ for $72 \mathrm{~h}$; + : Presence of clear zone; Detection of ChiA gene by PCR using 5'-TTCAYGTTCAACACTACAA-3 ' and 5'-CATTAAGGCCGCGGARTG-3' primers for B. subtilis SV41 and 5'-GATATCGACTGGGAGTTCCC-3 'and 5'-CATAGAAGTCGTAGGTCATC-3' primers for B. amyloliquefaciens subsp. plantarum SV65. g Protease activity: Tested on skim milk agar (3\% v v-1) medium and incubated at $28 \pm 2{ }^{\circ} \mathrm{C}$ for $48 \mathrm{~h}$; +: Presence of clear zone. h Detection of fengycin D (FenD) gene by PCR using 5'-TTTGGCAGCAGGAGAAGTTT-3' and 5'-GCTGTCCGTTCTGCTTTTTC-3'primers. i Salicylic acid production after $48 \mathrm{~h}$ incubation at $28 \pm 2^{\circ} \mathrm{C}$ in succinate medium; +: Production of salicylic acid. j Relative expression of lipoxygenase (LOXD) gene in uninoculated tomato plants with F. oxysporum f. sp. lycopersici (FOL) using 5'CCTGAAATCTATGGCCCTCA-3' and 5'-ATGGGCTTAAGTGTGCCAAC-3' primers for quantitative RT-PCR.

k Relative expression ofacidic chitinase (CHI3-PR3) gene in uninoculated tomato plants with FOL using 5'-

TGCAGGAACATTCACTGGAG-3' and 5'-TAACGTTGTGGCATGATGGT-3' primers for quantitative RT-PCR.

${ }^{1}$ Relative expression ofPR1 gene into inoculated tomato plants with FOL using 5'-TCTTGTGAGGCCCAAAATTC-3' and 5'-

ATAGTCTGGCCTCTCGGACA-3'primers for quantitative RT-PCR.

Before being used in the different bioassays, bacterial cultures were initiated from stock maintained at $-20^{\circ} \mathrm{C}$ in Nutrient Broth (NB) supplemented with $40 \%$ glycerol and grown for $48 \mathrm{~h}$ at $25^{\circ} \mathrm{C}$ on Nutrient Agar (NA) medium.

Test of the effect of Bacillus spp. strains on tomato growth and Fusarium wilt severity

Bacterial treatments were prepared from cultures previously grown in NB medium for 3 days at $28 \pm 2{ }^{\circ} \mathrm{C}$ and under continuous stirring at $150 \mathrm{rpm}$. They were firstly applied to tomato cv. Sahel seedlings by drenching the substrate of each alveolus $\left(3 \mathrm{~cm}\right.$ in diameter) with $5 \mathrm{ml}$ of a bacterial cell suspension $\left(10^{8}\right.$ cells $\mathrm{ml}^{-1}$ ). Treated and untreated tomato seedlings were transplanted into rows with a distance of $33 \mathrm{~cm}$ between seedlings. Planting was carried out on December 2015 under greenhouse installed in the experimental station of Teboulba, Monastir, Tunisia (N35³8'38,256", E1056'48,458"). Planting soil was known to be historically infected with FOL.

A second bacterial treatment was applied at planting, one week after the first treatment, by drenching the rhizospheric soil of each seedling with $100 \mathrm{ml}$ of a cell suspension $\left(10^{8}\right.$ cells ml-1). Three treatments were tested: (i) Untreated control seedlings, (ii) seedlings treated with B. subtilis SV41, and (iii) seedlings treated with B. amyloliquefaciens subsp. plantarum SV65.

Two replicates of twenty seedlings each were used for each individual treatment. Tomato seedlings were grown for about six months at $24-25^{\circ} \mathrm{C}$ with $16 / 8 \mathrm{~h}$ photoperiod and $70 \%$ air relative humidity. They were subjected to agricultural practices commonly adopted by farmers in the region and irrigated and fertilized as needed.

\section{Disease severity, growth and production parameters}

Six months after planting, the parameters noted were the vascular browning extent (from the collar), plant height, roots fresh weight, and fruits fresh weight per plant. The frequency of colonization of roots, collars and stems of tomato plants by pathogen was determined after isolation of ten fragments per organ on PDA medium amended with $300 \mathrm{mgl}^{-1}$ of streptomycin sulphate. For the latest parameter and for each organ, three replicates of one plate each were used for every individual treatment. Cultures were incubated at $25^{\circ} \mathrm{C}$ for 4 days. 
The percentage of colonization of plant tissues by various microorganisms was calculated using the formula of Moretti et al. (2008). The percentage of re-isolation from stems is the average of five counts recorded at different stem levels i.e. $(0$ to $5 \mathrm{~cm}),(5$ to $10 \mathrm{~cm}),(10$ to $15 \mathrm{~cm}),(15$ to $20 \mathrm{~cm})$ and $(20$ to $25 \mathrm{~cm})$. The averages vascular browning extent, plant height, roots fresh weight were estimated from thirty plants. The average weight of fruits produced per plant was determined by calculating the total weight of fruits harvested between April and June 2016 and dividing by the total number of plants (40 plants).

\section{Initial soil sampling and processing}

Composite soil samples from each individual plot were collected twice i.e. just before planting and after the last harvest. Uprooted soil samples collected after the last harvest were removed from: (i) the rhizophere of untreated control plants, (ii) the rhizosphere of plants treated with B. subtilis SV41 and (iii) the rhizosphere of plants challenged with B. amyloliquefaciens subsp. plantarum SV65. At each sampling date, twenty soil cores $(7 \mathrm{~cm}$ in diameter $\times 15 \mathrm{~cm}$ in depth) collected from each treatment were combined to make one composite soil per individual treatment. Two replicates were considered for each soil sampling. Once brought to laboratory, soil samples were passed through a 2-mm sieve to remove rocks and large organic debris. They were stored in plastic bags at $10^{\circ} \mathrm{C}$ and processed within 1 to 4 weeks after sampling (Larkin and Honeycutt, 2006). For further assays, two subsamples were processed from each composite soil sample.

\section{Determination of Fusarium oxysporum population}

To confirm the presence of $F$. oxysporum in the soil and to evaluate the effect of tested bacterial treatments on the soil infectious potential, $5 \mathrm{~g}$ of each soil sample were placed in an Erlenmeyer flask containing $100 \mathrm{ml}$ of sterile distilled water (SDW) and subjected to continuous stirring at $150 \mathrm{rpm}$ for $60 \mathrm{~min}$. The supernatant was filtered through a double layer of muslin followed by a series of dilutions using SDW (Daami-Remadi et al., 2009). For each sample, $200 \mu \mathrm{l}$ of $10^{-2}$ dilution were plated onto selective peptone-pentachloronitrobenzen (PCNB) agar medium specific for Fusarium spp. isolation (Nash and Snyder, 1962). Plates were stirred gently by hand for homogeneous distribution of the soil extract with the culture medium. Three replicates of one Petri plate each were used for each soil sample. After incubation at $25^{\circ} \mathrm{C}$ for 12 days, $F$. oxysporum colonies growing on PCNB agar medium were morphologically and microscopically identified and the total number of colonies was counted.

\section{Determination of soil properties}

Soil samples were air-dried before use. Soil extracts were prepared by suspending soil in distilled water in 1:10 soil/ $\mathrm{dH}_{2} \mathrm{O}$ ratio. They were filtered through Whatman paper No 1 and analyzed for determination of their $\mathrm{pH}$ and conductivity using a glass electrode and conductivity meter, respectively. Water content was checked by removing $5 \mathrm{~g}$ of soil and weighting it before (wet weight) and after oven drying at $105^{\circ} \mathrm{C}$ for $24 \mathrm{~h}$ (Larkin et al., 2006). Organic carbon was determined by drying $10 \mathrm{~g}$ of soil at $105^{\circ} \mathrm{C}$ overnight and then at $900^{\circ} \mathrm{C}$ for $2 \mathrm{~h}$. The percentage of organic matter was calculated using the following formula:

Organic matter $=($ dry matter - mineralized matter $) \times 100 /$ dry matter and the percentage of organic carbon was estimated using the following formula: \%Organic carbon = \%Organic matter / 1.72 (Kettler et al., 2001).

\section{Estimation of soil microbial community}

General populations of culturable soil microorganisms were determined by soil dilution plating on various agar media according to Larkin and Honeycutt (2006) with some modifications. For each subsample taken from each composite soil, $10 \mathrm{~g}$ were added to $90 \mathrm{ml}$ of sterile $0.2 \%$ water agar, vigorously stirred for $30 \mathrm{~min}$, serially diluted and a-100 $\mu$ sample wasplated on 10\% Tryptic Soy Agar (TSA) for total bacterial counts, selective King's B medium (KB) amended with $75 \mathrm{mg} \mathrm{l}^{-1}$ of penicillin and $75 \mathrm{mg} \mathrm{l}^{-1}$ of cyclohexamide for Pseudomonas fluorescens counts, Yeast Malt Agar (ISP medium No. 2) amended with $75 \mathrm{mg} \mathrm{l}^{-1}$ of nalidixic acid and $100 \mathrm{mg} \mathrm{l}^{-1}$ of cyclohexamide for actinomycete counts, and Potato Dextrose Agar (PDA) amended with $300 \mathrm{mg} \mathrm{l}^{-1} \mathrm{of}$ streptomycine sulphate for total fungal counts. Four replicates of one plate each were used for each soil subsample.

Bacterial and actinomycete plates were incubated at $28^{\circ} \mathrm{C}$ for 2 and 14 days, respectively, and fungal plates were maintained at $25^{\circ} \mathrm{C}$ for 7 days before counting growing colonies. Colonies of Aspergillus spp., Penicillium spp. and Fusarium spp. were identified based on their macro- and micro-morphological traits under light microscope and counted separately.

\section{Statistical analysis}

Data were subjected to a one-way analysis of variance (ANOVA) using Statistical Package for the Social Sciences (SPSS) software for Windows version 16.0. Data were analyzed according to a completely randomized design. Means were separated using Duncan Multiple Range tests to identify significant pairwise differences at $P \leq 0.05$. 


\section{Results}

\section{Effects of tested bacterial treatments on Fusarium wilt severity and tomato growth}

Six months after planting, a significant decrease (at $P \leq 0.05$ ) in Fusarium wilt severity was achieved following tested bacterial treatments as compared to control,. Indeed, the vascular browning extent was reduced by 82.3 and $88.2 \%$ by $B$. subtilis SV41 and B. amyloliquefaciens subsp. plantarum SV65 treatments, respectively, compared to the untreated control (Figure 1).

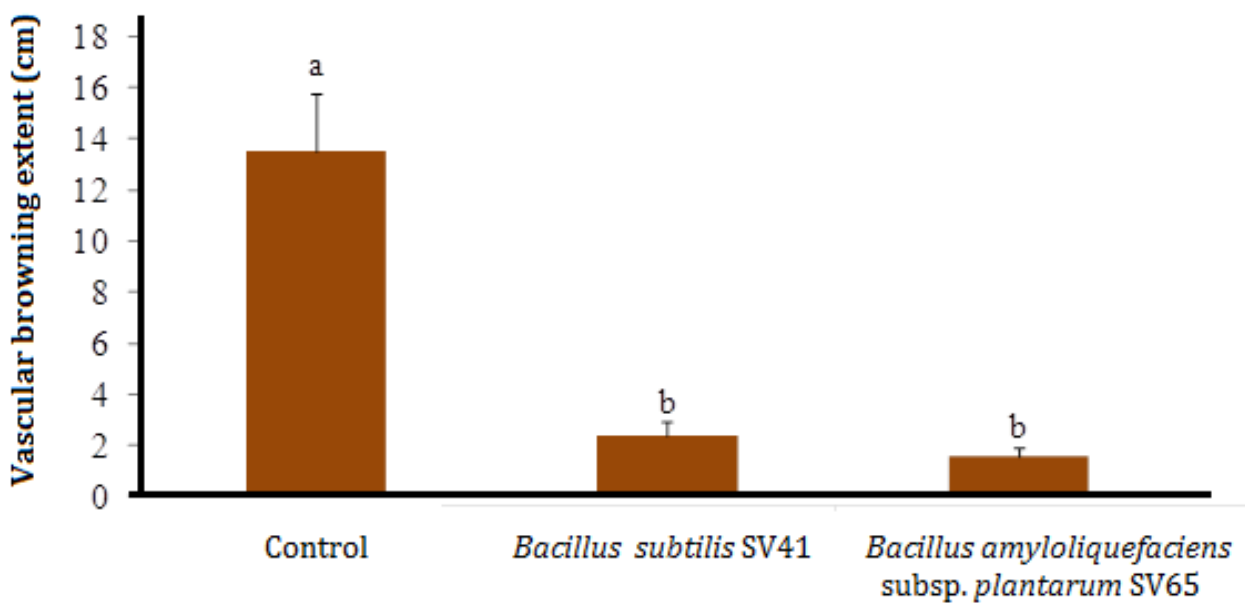

\section{Bacterial treatment}

Figure 1. Effect of Bacillus subtilis SV41 and Bacillus amyloliquefaciens subsp. plantarum SV65 on Fusarium wilt severity on tomato plants cv. Sahel grown under greenhouse for six months.

Results are presented as mean \pm SE $(n=30, P \leq 0.05)$. Bars sharing the same letter are not significantly different according to Duncan Multiple Range test at $\mathrm{P} \leq 0.05$.

The percentage of re-isolation of $F$. oxysporum from roots, collars and stems of plants treated with $B$. amyloliquefaciens subsp. plantarum SV65 and B. subtilis SV41 was limited to $2.6-46.6 \%$ and $10-53.3 \%$, respectively, compared to the untreated control where the re-isolation frequency of $F$. oxysporum varied from 63.3 to $80 \%$ (Figure 2).

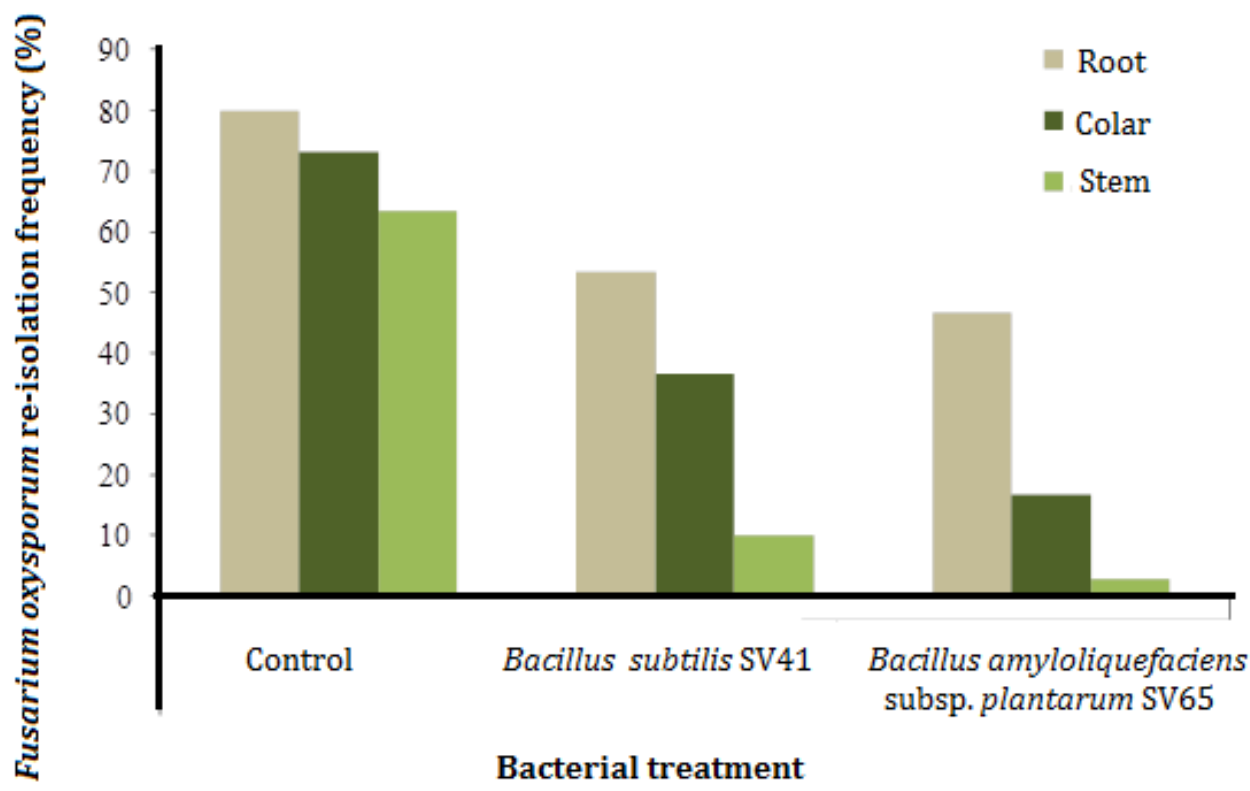

Figure 2. Effect of Bacillus subtilis SV41 and Bacillus amyloliquefaciens subsp. plantarum SV65 on Fusariumoxysporum re-isolation frequency from roots, collars and stems of tomato plants cv. Sahel grown under greenhouse for six months.

The values presented are the percentages (\%) of re-isolation of F. oxysporum on Potato Dextrose Agar (PDA) medium after incubation at $25^{\circ} \mathrm{C}$ for 4 days. Ten fragments per organ were cultured on plates containing PDA medium supplemented with streptomycin sulfate $(300 \mathrm{mg} \mathrm{l-1)}$. Each individual treatment was repeated three times $(3 \times 10$ fragments). The percentage of re-isolation from stems is the average of five counts recorded at different stem levels i.e. $(0$ to $5 \mathrm{~cm}),(5$ to $10 \mathrm{~cm}),(10$ to $15 \mathrm{~cm}),(15$ to $20 \mathrm{~cm})$ and $(20$ to $25 \mathrm{~cm})$. 
As given in Table 2, growth and production parameters of tomato plants cv. Sahel (plant height, root fresh weight and fruit production per plant), noted six months after planting, varied significantly (at $P \leq 0.05$ ) depending on tested bacterial treatments.

Concerning plant height, a significant improvement of this parameter, of about $10.6 \%$ over control, was achieved using B. amyloliquefaciens subsp. plantarum SV65 based treatment (Table 2). The root fresh weight was significantly increased by 15.6 and $16.3 \%$ versus control in tomato plants treated with $B$. amyloliquefaciens subsp. plantarum SV65 and B. subtilis SV41, respectively. As shown in Table 2, $B$. amyloliquefaciens subsp. plantarum SV65 and B. subtilis SV41 significantly improved the fruit production by 8.4 and $12.5 \%$ compared to the untreated control where the greatest enhancement, of about $12.5 \%$ over control, was recorded in B. subtilis SV41 treated plants.

Table 2. Effect of two Bacillus spp. strains on the growth of tomato plants cv. Sahel grown under greenhouse ${ }^{\mathrm{x}}$ for six months.

\begin{tabular}{lccc}
\hline Bacterial treatment & ${\text { Plant height }(\mathrm{cm})^{\mathrm{a}}}$ & ${\text { Root fresh weight }(\mathrm{g})^{\mathrm{b}}}$ & ${\text { Fruit weight }(\mathrm{g})^{\mathrm{c}}}$ \\
\hline Control & $321.7 \mathrm{~b} \pm 68$ & $51.5 \mathrm{~b} \pm 1.86$ & $1622 \mathrm{c} \pm 0.73$ \\
B. subtilis SV41 & $326.5 \mathrm{~b} \pm 67$ & $61.5 \mathrm{a} \pm 3.15$ & $1854 \mathrm{a} \pm 0.83$ \\
B. amyloliquefaciens subsp. plantarum SV65 & $359.17 \mathrm{a} \pm 51$ & $61.03 \mathrm{a} \pm 12$ & $1770 \mathrm{~b} \pm 0.8$ \\
\hline
\end{tabular}

For each column, the values followed by the same letter are not significantly different according to Duncan Multiple Range test at $P \leq$ $0.05 ; \pm$ SE: Standard error.

a,b Results are noted at harvest. The values presented are the averages obtained from 30 plants for each treatment. The broken plants were eliminated from the statistical analysis.

c Fruit weight was expressed per plant. For each treatment, this parameter was determined by calculating the sum of the weights of all fruits harvested between April and June 2016 divided by the total number of plants ( 40 plants).

$x$ The greenhouse is located in the experimental station at Teboulba (N35 ${ }^{\circ} 38^{\prime} 38.256$ ", E10 ${ }^{\circ} 566^{\prime} 48.458$ ", Monastir), The Regional Research Centre on Horticulture and Organic Agriculture of Chott-Mariem, Tunisia.

\section{Effects of tested bacterial treatments on Fusarium oxysporum population}

ANOVA analysis performed for the number of $F$. oxysporum colonies revealed a significant variation (at $P \leq$ 0.05 ) in this parameter depending on sampled soils. As given in Figure3, F. oxysporum colonies were reduced by 87.5 and $91.7 \%$ in soils sampled from the rhizosphere of tomato plants cv. Sahel treated with B. subtilis SV41 and B. amyloliquefaciens subsp. plantarum SV65, respectively, as compared to those sampled before planting (initial soil state). F. oxysporum population decreased by 88.4 and $92.3 \%$ in tomato rhizospheric soils, compared to controlsoils, following their treatment with B. subtilis SV41 and B. amyloliquefaciens subsp. plantarum SV65, respectively.

\section{Effect of tested bacterial treatments on soil properties}

All collected soil samples were sandy loam. The application of bacterial treatments did not induce significant changes in soil pH which ranged between 7.3 and 7.7. However, the conductivity decreased by 26.7 and 42.1\%in soils treated with B. amyloliquefaciens subsp. plantarum SV65 and B. subtilis SV41 compared to control and by 23.7 and $39.7 \%$ relative to the initial state, respectively (Table 3 ).

Table 3. Properties of sampled soils a

\begin{tabular}{|c|c|c|c|c|c|c|c|}
\hline Soil sample & Sampling date & Texture & $\mathrm{pH}$ & $\begin{array}{c}\mathrm{EC} \\
(\mathrm{dS} / \mathrm{m})\end{array}$ & $\begin{array}{c}\text { Water } \\
\text { content }(\%) \\
\end{array}$ & $\begin{array}{c}\text { Organic } \\
\text { matter }(\%)\end{array}$ & $\begin{array}{c}\text { Organic } \\
\text { carbon }(\%)\end{array}$ \\
\hline Initial state & December 2015 & Sandy loam & 7.3 & 0.228 & 15 & 3.16 & 1.83 \\
\hline Control & June 2016 & Sandy loam & 7.7 & 0.237 & 15.5 & 2.74 & 1.59 \\
\hline SV41-treated & June 2016 & Sandy loam & 7.6 & 0.137 & 15.5 & 3.38 & 1.96 \\
\hline SV65-treated & June 2016 & Sandy loam & 7.4 & 0.174 & 13.5 & 3.66 & 2.13 \\
\hline
\end{tabular}

a Soil sampled from the greenhouse located in the experimental station at Teboulba (N35 38'38.256 ", E10 $56^{\prime} 48.458$ ", Mon astir),

The Regional Research Centre on Horticulture and Organic Agriculture of Chott-Mariem, Tunisia.

Initial state: Soil sampled one week before planting. Control: Soil sampled from the rhizosphere of untreated tomato plants six months after planting.SV41: Soil sampled from the rhizosphere of tomato plants treated with Bacillus subtilis SV41. SV65: Soil sampled from the rhizosphere of tomato plants treated with B. amyloliquefaciens subsp. plantarum SV65.

The percentage of water content varied from 13.5 to $15.5 \%$ in all soil samples. A slight increment of about 23.4 and 33.7\% $\mathrm{n}$ the percentage of organic matter was noted in the soil removed around roots of tomato plants treated with B. subtilis SV41 and B. amyloliquefaciens subsp. plantarum SV65 compared to control soil sampled on June 2016 and of about 6.9 and 15.8\%relative to the initial soil state sampled on December 2015 , respectively. Additionally, the percentage of organic carbon varied from 1.96 to $2.13 \%$ in soil treated separately with B. subtilis SV41 and B. amyloliquefaciens subsp. plantarum SV65 compared to 1.59 and $1.83 \%$ estimated on control and initial soil samples, respectively (Table 3). 


\section{Effects of tested bacterial treatments on soil microbial community}

Analysis of variance revealed that the number of bacterial colonies growing from plated soil samples, after 2 days of incubation in TSA medium, varied significantly (at $P \leq 0.05$ ) depending on tested treatments. Soil samples treated with $B$. subtilis SV41 and B. amyloliquefaciens subsp. plantarum SV65 showed significant increase in their bacterial populations of about $78.5710^{6}$ and $58.1210^{6} \mathrm{CFU} \mathrm{g}^{-1}$ soil, respectively, as compared to the initial soil state (before planting) estimated at $16.7510^{6} \mathrm{CFUg}^{-1}$. A significant enhancement, of about $49.9 \%$, in the total culturable bacterial community was recorded in the tomato rhizospheric soil treated with B. subtilis SV41 compared to control (Figure 4A).

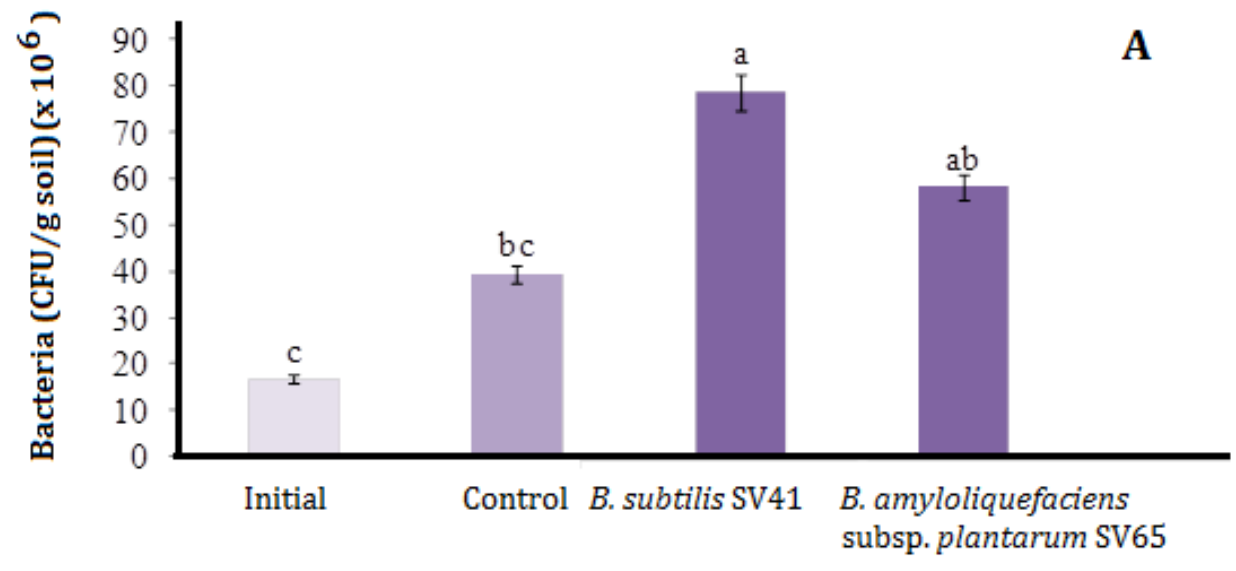

Soil samples

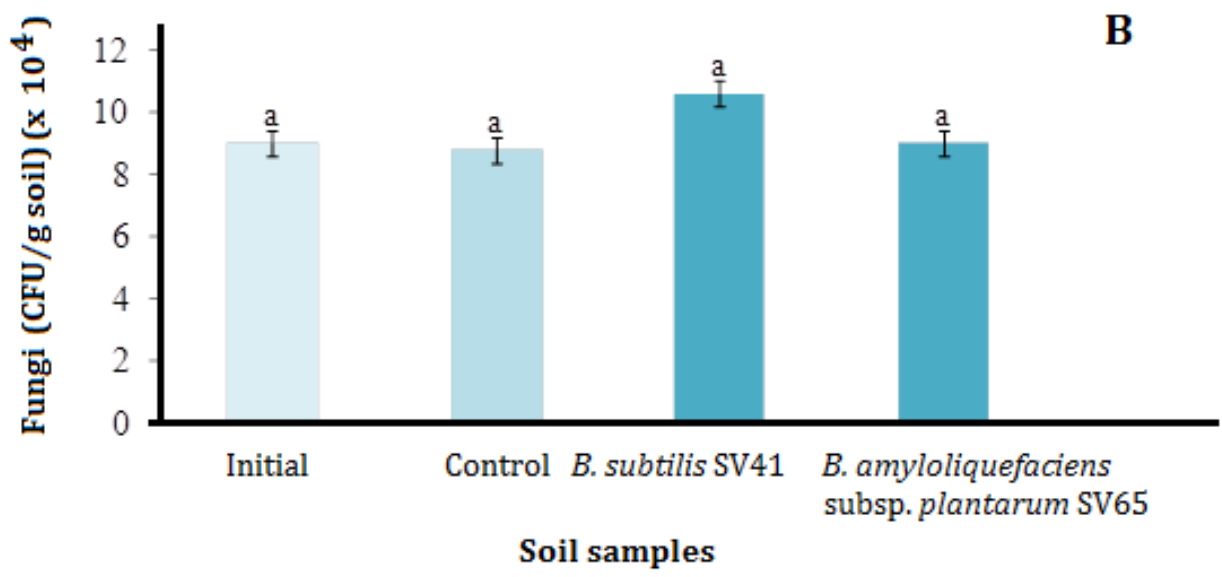

Figure 4.Effect of bacterial treatment on soil microbial population sampled from the rhizosphere of tomato plants grown under greenhousex for six months.

Results are presented as mean $\pm \mathrm{SE}(\mathrm{n}=8, P \leq 0.05)$. Bars sharing the same letter are not significantly different according to Duncan Multiple Range test at $p \leq 0.05$. Dilution was made from a concentration of $10 \%$ ( $\mathrm{w} \mathrm{v}^{-1}$ ).Initial: Soil sampled at pre-plant (before planting). Control: Soil sampled from the rhizosphere of untreated tomato plants at the end of the trial (six months after planting). $x$ The greenhouse is located in the experimental station at Teboulba (N35 ${ }^{\circ} 38^{\prime} 38.256$ ", E10 ${ }^{\circ} 56^{\prime} 48.458$ ", Monastir), The Regional Research Centre on Horticulture and Organic Agriculture of Chott-Mariem, Tunisia.

As for the bacterial biodiversity, the relative abundance of Pseudomonas spp. community was found to be relatively important in the rhizosphere of tomato plants treated with the two bacterial strains and in the untreated ones as compared to Pseudomonas population determined in the initial soil state (Figure 5). Indeed, both bacterial treatments significantly enriched Pseudomonas community in treated soils by 57.5$66 \%$ compared to the control soils and by $92.8-94.2 \%$ versus the initial soil state. Furthermore, P. fluorescens colonies were three times higher in the B. amyloliquefaciens subsp. plantarum SV65-treated soil than in control soil and 11.2 times more abundant than in theinitial state. Soil treated with B. subtilis SV41 showed significant increase in $P$. fluorescens population which was nine times higher than that ofthe initial soil (Table 4). As shown Figure5, in each soil sample, Actinomycetes population was lesser when compared to the remaining bacterial groups. Indeed, Actinobacteria population significantly increased by 52 and $56.2 \%$, compared to the initial state, in soils treated with both bacterial strains. Furthermore, B. subtilis SV41treated soil showed significant increment in the total of culturable Actinomycetes of about $44.9 \%$ compared to control (Table 4). 
Table 4. Soil populations of selected subgroups of microorganisms isolated from the rhizosphere of tomato cv. Sahel plants treated separately with Bacillus subtilis SV41 and Bacillus amyloliquefaciens subsp. plantarum SV65 compared to the untreated and to the pre-plant soil samples, as determined by soil dilution plating on selective media.

\begin{tabular}{lcccccc}
\hline Soil sample & \multicolumn{5}{c}{ Microorganism group (CFU g-1 soil) ${ }^{\mathrm{x}}$} \\
\cline { 2 - 7 } & $\begin{array}{c}\text { Actinomycetes } \\
\left(\times 10^{3}\right)\end{array}$ & $\begin{array}{c}\text { Pseudomonas } \\
\left(\times 10^{5}\right)\end{array}$ & $\begin{array}{c}\text { P.fluorescens } \\
\left(\times 10^{5}\right)\end{array}$ & $\begin{array}{c}\text { Aspergillus } \\
\text { spp. }\left(\times 10^{3}\right)\end{array}$ & $\begin{array}{c}\text { Penicillium } \\
\text { spp. }\left(\times 10^{3}\right)\end{array}$ & $\begin{array}{c}\text { Fusarium spp. } \\
\left(\times 10^{3}\right)\end{array}$ \\
\hline Initial state & $15.00 \mathrm{c}$ & $15.00 \mathrm{~b}$ & $5.00 \mathrm{c}$ & $13.75 \mathrm{~b}$ & $0 \mathrm{~b}$ & $25.00 \mathrm{a}$ \\
Control & $18.88 \mathrm{bc}$ & $88.75 \mathrm{~b}$ & $18.75 \mathrm{bc}$ & $16.66 \mathrm{ab}$ & $0 \mathrm{~b}$ & $26.66 \mathrm{a}$ \\
SV41-treated & $34.28 \mathrm{a}$ & $261.25 \mathrm{a}$ & $45.00 \mathrm{ab}$ & $27.50 \mathrm{a}$ & $6.25 \mathrm{a}$ & $7.50 \mathrm{~b}$ \\
SV65-treated & $31.25 \mathrm{ab}$ & $208.75 \mathrm{a}$ & $56.25 \mathrm{a}$ & $21.25 \mathrm{ab}$ & $1.25 \mathrm{ab}$ & $2.50 \mathrm{~b}$ \\
\hline
\end{tabular}

x Soil samples were collected in December 2015 (before planting) and June 2016 (harvest) from the greenhouse located in the experimental station at Teboulba (N35 ${ }^{\circ} 38 ' 38.256^{\prime \prime}$ E10 ${ }^{\circ} 56^{\prime} 48.458$ ", Monastir), The Regional Research Centre on Horticulture and Organic Agriculture of Chott-Mariem, Tunisia.

Values following with the same letter are not significantly different according to Duncan Multiple Range test at $P \leq 0.05$. Dilution was made from a concentration of $10 \%\left(\mathrm{w} \mathrm{v}^{-1}\right)$. Initial: Soil sampled at pre-plant (before planting). Control: Soil sampled from the rhizosphere of untreated tomato plants at the end of the trial (six months after planting).B1: Soil sampled from the rhizosphere of tomato treated with Bacillus subtilis SV41. B2: Soil sampled from the rhizosphere of tomato treated with B. amyloliquefaciens subsp. plantarum SV65.

As for fungal biodiversity, there was a slight increase in the total culturable fungi, growing after 7 days of incubation in PDA medium, following bacterial treatments compared to control and initial soil samples (Figure 4B). As given in Table 3, Aspergillus spp. and Penicillium spp. colonies were more abundant in the rhizosphere of B. subtilis SV41-treated plants compared to the initial (before tomato planting) and control soil samples. However, a significant decrease by 71.9 and $90.6 \%$ compared to control soil and by 70 and $90 \%$ relative to the initial state, was noted in Fusarium spp. populations in soils treated with B. subtilis SV41 and B. amyloliquefaciens subsp. plantarum SV65, respectively (Table 4).

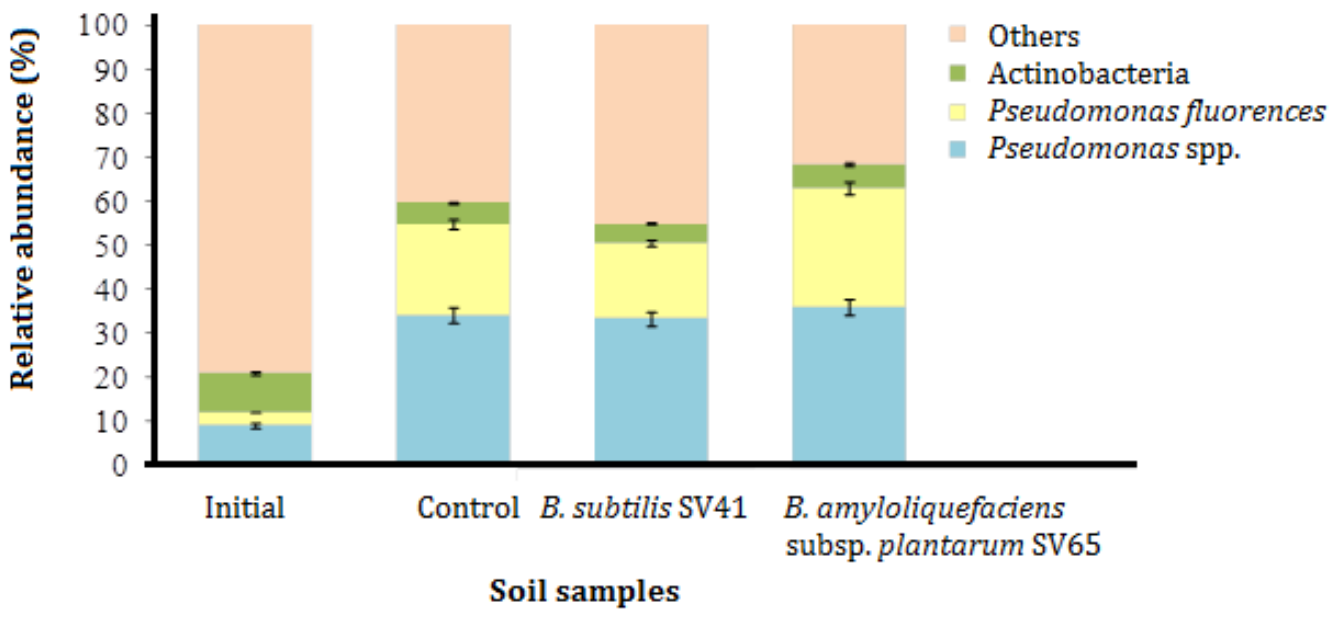

Figure 5 . The bacterial community structure under bacterial soil treatment per g soil.

Results are presented as mean \pm SE $(n=8, P \leq 0.05)$. The relative abundance was estimated per the total bacteria counted in each sampled soil. Dilution was made from a concentration of $10 \%\left(\mathrm{w} \mathrm{v}^{-1}\right)$. Initial: Soil sampled at pre-plant

(before planting). Control: Soil sampled from the rhizosphere of untreated tomato plants at the end of the trial (six months after planting).

\section{Discussion}

A better understanding of what makes a plant-microbe interaction detrimental or beneficial to plants would provide an important insight into the efficient handling of microbes for agriculture production (Swarupa et al., 2016). In this study, two endophytic bacteria, B. subtilis SV41 and B. amyloliquefaciens subsp. plantarum SV65, were assessed for their ability to suppress Fusarium wilt disease symptoms, to enhance tomato growth and production and to reduce pathogen inoculums in soil. The effect of both bacteria on soil microbial populations was also estimated.

The exploration of endophytic bacteria as a potentially interesting and environmentally friendly alternative for the management of tomato Fusarium wilt disease has been shown to be effective in inhibiting systemic progression of the causative agent (Ramyabharathi and Raguchander, 2014). In this study, B. subtilis SV41 and B. amyloliquefaciens subsp. plantarum SV65 successfully reduced Fusarium wilt severity by $82-88 \%$ and limited the pathogen colonization of tomato stems compared to control. Numerous plant pathogenic $F$. oxysporum isolates were successfully controlled by Bacillus sp. recovered from chickpea plants (Landa et al., 1997). Disease suppressive effects were also expressed by two unidentified endophytic bacteria, recovered 
from healthy wild and cultivated young oilseed rape plants, which reduced Fusarium wilt severity by $75 \%$ on tomato plants (Nejad and Johnson, 2000). Kalai-Grami et al. (2014) found that endophytic B. mojavensis recovered from citrus plants reduced disease severity in maize plants inoculated with Fusarium verticillioides. In addition, most Bacillus species were able to inhibit the mycelial growth of $F$. oxysporumin vitro (Idris et al., 2007; Aydi Ben Abdallah et al., 2015).

The plant growth-promoting ability was induced by the beneficial microbial agents directly by the acquisition of essential nutriments and the production of phytohormones and/or indirectly by inhibiting pathogen growth and inducing plant systemic resistance (Santoyo et al., 2016). Results from the current study clearly demonstrated that application of B. subtilis SV41 and B. velezenis SV65 in the soil reduced the population of $F$. oxysporum and enhanced the number of beneficial microbial agents leading to a significant decrease in Fusarium wilt severity and to a significant promotion of plant growth and production. This result is in agreement, in part, with previous findings related to disease-suppressive effects displayed by an endophytic B. subtilis EPC016, isolated from cotton plants, which decreased Fusarium wilt incidence by $68.4 \%$ and increased tomato growth and yield compared to control (Ramyabharathi and Raguchander, 2014). B. subtilis SV41 and B. amyloliquefaciens subsp. plantarum SV65 were previously tested with other Bacillus species in a pot experiment where authors indicated that Fusarium wilt severity suppression was significantly correlated to the decreaseof pathogen colonization of vascular tissues leading consequently to plant growth promotion (Aydi Ben Abdallah et al., 2017). Indeed, B. subtilis SV41 was found the highest salicylic acid producing agent that acts as an elicitor for the induction of systemic resistance against pathogen attack. Furthermore, Aydi Ben Abdallah et al. (2017) found that B. amyloliquefaciens subsp. plantarum SV65induced expression of the lipooxygenase gene (LOXD) and especially acidic PR-1 and PR-3 genes in treated plants and those uninoculated or inoculated with FOL. Therefore, the two Bacillus spp., tested in our study, have shown able to induce systemic resistance in treated tomato as reported in Aydi Ben Abdallah et al. (2017) leading indirectly to growth promotion. There are a large number of common mechanisms that plant growth-promoting bacteria (PGPB) use to indirectly promote plant growth which include production of antibiotics and cell wall-degrading enzymes, decrease in ethylene levels, induction of systemic resistance, reduction of iron available to pathogens, and synthesis of pathogen-inhibiting volatile compounds (Glick, 2015). In addition, PGPB directly promote plant growth through the acquisition of nutriments from environment including nitrogen, phosphorous and iron or through the production and/or regulation of various plant hormones including auxin, cytokinin or ethylene (Santoyo et al., 2016). These two Bacillus strains tested in the current investigation are shown able to produce the indole 3-acetic acid (IAA) and only B. amyloliquefaciens subsp. plantarum SV65 was able to solubilize the phosphate (unpublished data). Aydi Ben Abdallah et al. (2016) also demonstrated that Bacillus sp. SV101 and B. tequilensis SV104 were IAA-producing agents and only Bacillus sp. SV101 was a phosphate-solubilizing strain.

Many researchers have attempted the development of biocontrol agents for suppression of various soilborne pathogens (Domenech et al., 2005). In this study, pre-planting soil treatment with B. subtilis SV41 and $B$. amyloliquefaciens subsp. plantarum SV65 reduced Fusarium (and especially $F$. oxysporum) inoculum in treated soils as compared to control. These results are in agreement with other findings (Zhang et al., 2008; Ling et al., 2010). In fact, Qiu et al. (2012) found that following treatment with abio-organic fertilizer (composed of organic fertilizer combined with B.subtilis SQR-9, Paenibacillus polymyxa SQR-21 and Trichoderma harzianum SQR-T037), Fusarium population was reduced to one fourth as compared the organic fertilizer applied without microbial supply. Indeed, among the Fusarium group, F.oxysporum population in soils unsubjected to microbial amendment were almost ten times more abundant than in the soil treated with the bio-organic fertilizer. In this study, the abundance of fungi showed different trends. A higher frequency of Aspergillus and Penicillium colonies was detected in the rhizosphere of tomato plants treated with B. subtilis SV41 as compared to the initial state (before planting) and to control soil. Aspergillus and Penicillium have been reported to be antagonistic to various Fusarium species (Dong and Cohen, 2002; Brzezinska and Jankiewicz, 2012; Mejdoub-Trabelsi et al., 2017). In fact, Sreevidya and Gopalakrishnan (2016) demonstrated that $P$. citrinum VFI-51 is able to produce siderophores, indole 3-acetic acid, hydrocyanic acid, lipase, protease, $\beta-1,3$ glucanase, and volatile compounds and also capable to compete with other pathogenic microorganisms such as Fusarium species (Aydi Ben Abdallah et al., 2015; MejdoubTrabelsi et al., 2017).

As for their effects on bacterial community structure, the number of beneficial bacteria determined in bacterized soils was three times higher than in the initial soil state (before planting). Moreover, B. subtilis SV41-treated soil showed enrichment of the total bacteria populations as compared to control. These 
findings are in agreement with those of Qiu et al. (2012). In the current study, the soil DNA was not extracted and pyrosequenced. The colonies number of Actinomycetes and Pseudomonas wereestimatedbased on their macro-morphological traits on selective media. The number of Pseudomonas spp. was significantly higher in treated soils than in control ones (initial state and untreated control). The application of B. amyloliquefaciens subsp. plantarum SV65 in soil enhanced the population of $P$. fluorescens as compared to the initial state and to control soil. Pseudomonas is also known by its ability to suppress numerous plant pathogens including F.oxysporum (Patel et al., 2012; Munif et al., 2012; Dalal and Kulkarni, 2013). Bibi et al. (201) and Aydi Ben Abdallah et al. (2016) showed the ability of Pseudomonas spp. to produce hydrolytic enzymes such as chitinase, protease, pectinase and $\beta-1,3$ glucansewhich are involved in the antifungal activity againstF.oxysporum. Also, in the current study, Actinobacteria population was significantly increased in soils treated with both bacterial strains compared to the initial soil state. In fact, B. subtilis SV41-treated soil showed significant enrichment in Actinomycetes population which was estimated to be two times higher than to that of the untreated soil. Qiu et al. (2012) found that Streptomyces, an Actinobacteria, accounted for $3.2 \%$ of the total bacterial sequences on soils treated with various microbial inoculants such as Bacillus, Paenibacillus and Trichoderma. Its abundance is approximately three times higher than in the untreated soil. This genus can produce tubercidin, phosphlactomycin and candicidin (Hwang et al., 1994) and was found to be an effective biological control agent (Etebarian et al., 2003; Nourozian et al., 2006; Shekhar et al., 2006). Actinomycetes collected from 30 rhizospheric soils of Catharanthus roseus and Withania somnifera in different locations in Ludhiana, India, are promising biocontrol agents for Alternaria alternata, Fusarium oxysporum, Helminthosporium oryzae, Macrophomina phaseolina, Penicillium sp., Rhizoctoniasolani and Sclerotium rolfsii control (Kamara and Gangwar, 2015).

Fusarium wilt suppression maybe, in part, attributed to the action of microbial agents associated to treated tomato plants. In this study, soil bacterial treatment increased significantly the populations of Pseudomonas and Actinomycetes in tomato rhizosphere compared to untreated soils. Patel et al. (2012) identified an endophytic Pseudomonas aeruginosa HR7, recovered from cultivated tomato, as an effective agent for $F$. oxysporum biocontrol. Dalal and Kulkarni (2013) also recorded a significant inhibition of F.oxysporum mycelial growth using endophytic Pseudomonas sp. originally recovered from soybean. In Aydi Ben Abdallah et al. (2016) study, P. brenneri S85, shown able to inhibit FOL in vitro and in vivo growth, was capable to produce chitinase, protease and pectinase. Endophytic Pseudomonas species i.e P. brenneri, P. koreensis, $P$. viridiflava and $P$. syringae are also commonly known as producers of antibiotics such as ecomycins and pseudomycins (Christina et al., 2013) and/or hydrolytic enzymes (Bibi et al., 2012). Indeed, two actinomycetes species i.eMicromonospora sp. and M. globosa were successfully explored as biocontrol agents against tomato wilt and Pigeons-peas wilts caused by F. oxysporum f. sp. lycopersici and F. udum, respectively (Smith, 1957; Ypadhyay and Rai, 1987). Various antifungal antibiotics were released in soils by different actinomycetes (Trejo-Estrada et al., 1998; El-Tarabily and Sivasithamparam, 2006). In fact, this bacterial group produced high levels of chitinases and $\beta$-1,3-glucanses which caused extensive hyphal plasmolysis, cell-wall lysis and significantly reduced the level of disease incidence under controlled greenhouse conditions (El-Tarabily et al., 2000). Furthermore, the plant growth-promoting potential noted in treated plants may be due to the presence of beneficial microorganisms in the rihzosphere of treated plants such as Pseudomonas and actinobacteria. Several previous study showed that phosphate solubilization potential and IAA production ability by Pseudomonasare involved in plant growth promotion (Ngamau et al., 2012; Patel et al., 2012; Dalal and Kulkarni, 2013; Aydi Ben Abdallah et al., 2016). Additionally, the selected actinomycetes, identified as Streptomyces using 16S rDNA analysis, have good plant growth-promotion and biocontrol potentials on chickpea under in vitro and in vivo conditions and were found able to produce siderophores, cellulases, lipapses, chitinases, proteases, $\beta$-1,3-glucanses, hydrocyanic acid and IAA (Sreevidya et al., 2016).

In conclusion, soil bacterial treatment using B. subtilis SV41 (KR818071) and B. amyloliquefaciens subsp. plantarum SV65 (KR818073) was considered to be an effective approach to suppress Fusarium wilt of tomato through the direct inhibition of the causal agent and the suppression of its inoculum in soil and also through the enhancement of the soil biofertility via its enrichment with various beneficial microbial agents.

\section{Acknowledgement}

This work was funded by the Ministry of Higher Education and Scientific Research of Tunisia through the funding allocated to the research unit UR13AGR09-Integrated Horticultural Production in the Tunisian Centre-East, Regional Research Centre on Horticulture and Organic Agriculture of Chott-Mariem, Tunisia, and by IRESA through the funding attributed to the multidisciplinary and the multi-institutional project CleProD. 


\section{References}

Aydi Ben Abdallah, R., Jabnoun-Khiareddine, H., Mokni-Tlili, S., Nefzi, A., Medimagh-Saidana, S., Daami-Remadi, M., 2015. Soil-borne and Compost-borne Aspergillus Species for Biologically Controlling Post-harvest Diseases of Potatoes Incited by Fusarium sambucinum and Phytophthora erythroseptica. Journal of Plant Patholology and Microbiology 6(10): 324-330.

Aydi Ben Abdallah, R., Jabnoun-Khiareddine, H., Nefzi, A., Mokni-Tlili, S., Daami-Remadi, M., 2016a. Biocontrol of Fusarium wilt and growth promotion of tomato plants using endophytic bacteria isolated from Solanum elaeagnifolium stems. Journal of Phytopathology 164(10): 811-824.

Aydi Ben Abdallah, R., Jabnoun-Khiareddine, H., Nefzi, A., Mokni-Tlili, S., Daami-Remadi, M., 2016b. Endophytic bacteria from Datura metel for plant growth promotion and bioprotection against Fusarium wilt in tomato. Biocontrol Science and Technology 26(8): 1139-1165.

Aydi Ben Abdallah, R., Stedel, C., Garagounis, C., Nefzi, A., Jabnoun-Khiareddine, H., Papadopoulou, K.P., Daami-Remadi, M., 2017. Involvement of lipopeptide antibiotics and chitinase genes and induction of host defense in suppression of Fusarium wilt by endophytic Bacillus spp. in tomato. Crop Protection 99:45-58.

Barraquio, W.L., Revilla, L., Ladha, L.K., 1997. Isolation of endophytic diazotrophic bacteria from wetland rice. Plant and Soil 194(1-2):15-24.

Bernard, E., Larkin, R.P., Tavantzis, S., Erich, M.S., Alyokhin, A., Gross, S.D., 2014. Rapeseed rotation, compost and biocontrol amendments reduce soilborne diseases and increase tuber yield in organic and conventional potato production systems. Plant and Soil 374(1-2): 611-627.

Bibi, F., Yasir, M., Song, G.C., Lee, S.Y., Chung, Y.R., 2012. Diversity and characterization of endophytic bacteria associated with tidal flat plants and their antagonistic effects on Oomycetous plant pathogens. The Plant Pathology Journal 28(1): 20-31.

Brzezinska, M.S., Jankiewicz, U., 2012. Production of antifungal chitinase by Aspergillus niger LOCK 62 and its potential role in the biological control. Current Microbiology 65(6): 666-672.

Christina, A., Christapher, V., Bhore, S.J., 2013. Endophytic bacteria as a source of novel antibiotics: An overview. Pharmacognosy Reviews 7: 11-16.

Compant, S., Reiter, B., Sessitsch, A., Nowak, J., Clément, C., Ait Barka, E., 2005. Endophytic colonization of Vitis vinifera L. by plant growth-promoting bacterium Burkholderia sp. strain PsJN. Applied and Environmental Microbiology 71: 1685-1693.

Daami-Remadi, M., Souissi, A., Ben Oun, H., Mansour, M., Nasraoui, B., 2009. Salinity effects on Fusarium wilt severity and tomato growth. Dynamic Soil, Dynamic Plant 3: 61-69.

Dalal, J., Kulkarni, N., 2013. Antagonistic and plant growth promoting potentials of indigenous endophytic bacteria of soybean (Glycine max (L) Merril). Current Research in Microbiology and Biotechnology 1(2): 62-69.

Domenech, J., Reddy, M.S., Kloepper, J.W., Ramos, B., Gutierrez-Maňero, J., 2005. Combined application of the biological product LS213 with Bacillus, Pseudomonas or Chryseobacterium for growth promotion and biological control of soil-borne diseases in pepper and tomato. BioControl 51:245-258.

Dong, H., Cohen, Y., 2002. Induced resistance in cotton seedlings against Fusarium wilt by dried biomass of Penicillium chrysogenum and its water extract. Phtoparasitica 30(1): 77-87.

Dubey, R.K., Tripathi, V., Dubey, P.K., Singh, H.B., Abhilash, P.C., 2016. Exploring rhizospheric interactions for agricultural sustainability: the need of integrative research on multi-trophic interactions. Journal of Cleaner Production 115: 362-365.

El-Tarabily, K.A., Sivasithamparam, K., 2006. Non-streptomycete actinomycetes as biocontrol agents of soil-borne fungal plant pathogens and as a plant growth-promoters. Soil Biology and Biohemistry 38(7): 1505-1520.

El-Tarabily, KA., Soliman, M.H., Nassar, A.H., Al-Hassani, H.A., Sivasithamparam, K., McKenna, F., Hardy, G.E.St.J., 2000. Biological control of Sclerotinia minor using a chitinolytic bacterium and actinomycetes. Plant Pathology 49: 573583.

Etebarian, H.R., Scott, E.S., Wicks, T.J., 2003. Evaluation of Streptomyces strains as potential biological agents of Phytophthora erythroseptica. Iranian Journal of Plant Pathology 49: 49-63.

Figueiredo, M.D.V.B., Bonifacio, A., Rodrigues, A.C., de Araujo, F.F., Stamford, N.P., 2016. Beneficial microorganisms: Current challenge to increase crop performance. In: Bioformulations: for Sustainable Agriculture, Arora et al., (Eds.). Springer India, pp. 53-70.

Glick, B.R., 2015. Beneficial Plant-Bacterial Interactions: Biocontrol mechanisms. Springer, Cham.

Hallmann, J., Quadt-Hallmann, A., Mahaffee, W.F., Kloepper, J.W., 1997. Bacterial endophytes in agricultural crops. Canadian Journal of Microbiology 43(10): 895-914.

Hwang, B.K., Ahn, S.J., Moon, S.S., 1994. Production, purification, and antifungal activity of the antibiotic nucleoside, tubercidin, produced by Streptomyces violaceoniger. Canadian Journal of Botany 72(4): 480-485.

Idris, H.A., Labushagne, N., Korsten, L., 2007. Screening rhizobacteria for biological control of Fusarium root and crown rot of sorghum in Ethiopia. Biological Control 40(1): 97-106. 
Kalai-Grami, L., Saidi, S., Bachkouel, S., Ben Slimene, I., Mnari-Hattab, M., Hajlaoui, M.R., Limam, F., 2014. Isolation and characterization of putative endophytic bacteria antagonistic to Phoma tracheiphila and Verticillium albo-atrum. Applied Biochemistry and Biotechnology 174(1): 365-375.

Kamara, V., Gangwar, M., 2015. Antifungal activity of actinomycets from rhizospheric soil of medicinal plants against phytopathogenic fungi. International Journal of Current Microbiologyand Applied Sciences 4(3): 182-187.

Kettler, T.A., Doran, J.W., Gilbert, T.L., 2001. Simplified method for soil particle-size determination to accompany soilquality analyses. Soil Science Society of American Journal 65(3): 849-852.

Landa, B.B., Hervfis, A., Bettiol, W., Jimnez-Diaz, R.M., 1997. Antagonistic activity of Bacteria from the chickpea rhizosphere against Fusarium Oxysporum f. sp. Ciceris. Phytoparasitica 25(4): 305-318.

Larkin, R.P., Tavantzis, S., 2013. Use of biocontrol organisms and compost amendments for improved control of soilborne diseases and increased potato production. American Journal of Potato Research 90(3): 261-270.

Larkin, R.P., Honeycutt, C.W., 2006. Effects of different 3-year cropping systems on soil microbial communities and rhizoctonia diseases of potato. Phytopathology 96(1): 69-79.

Larkin, R.P., Honeycutt, C.W., Griffin, T.S., 2006. Effect of swine and dairy manure amendments on microbial communities in three soils as influenced by environmental conditions. Biology and Fertility of Soils 43(1): 51-61.

Ling, N., Xue, C., Huang, Q., Yang, X., Xu, Y., Shen, Q., 2010. Development of a mode of application of bioorganic fertilizer for improving the biocontrol efficacy of Fusarium wilt. Biological Control 55(5): 673-683.

Mazzola, M., 2004. Assessment and management of soil community structure for disease suppression. Annual Review of Phytopathology 42: 35-59.

Meena, S.K., Meena, V.S., 2017. Importance of soil microbes in nutrient use efficiency and sustainable food production. In: Agriculturally important microbes for sustainable agriculture: Application in crop production and protection, Meena, V.S., Mishra, P.K., Bisht, J.K., Pattanayak, A., (Eds.). Springer Nature Singapore, pp. 3-23.

Mejdoub-Trabelsi, B., Aydi Ben Abdallah, R., Ammar, N., Daami-Remadi, M., 2017. Antifungal potential of extracellular metabolites from Penicillium pp. and Aspergillus spp. naturally associated to potato against Fusarium species causing tuber dry rot. Journal of Microbial and Biochemistry Technology 9(4): 181-190.

Moretti, M., Gilardi, G., Gullino, M.L., Garibaldi, A., 2008. Biological control potential of Achromobacter xylosoxydans for suppressing Fusarium wilt of tomato. International Journal of Botany 4:369-375.

Munif, A., Hallmann, J., Sikora, R.A., 2013. The influence of endophytic bacteria on Meloidogyneincognita infection and tomato plant growth. International Society for Southeast Asian Agricultural Sciences 19(2): 68-74.

Nash, S.M., Snyder, W.C., 1962. Quantitative estimations by plate counts of propagules of the bean root rot Fusarium in field soils. Phytopathology 52(6): 567-572.

Nejad, P., Johnson, P.A., 2000. Endophytic bacteria induce growth promotion and wilt disease suppression in oilseed rape and tomato. Biological Control 18(3): 208-215.

Ngamau, C.N., Matiru, V.N., Tani, A., Muthuri, C.W., 2012. Isolation and identification of endophytic bacteria of bananas (Musa spp.) in Kenya and their potential as biofertilizers for sustainable banana production. African Journal of Microbiology Research 6: 6414-6422.

Nourozian, J., Etabarian, H.R., Khodakaramian, G., 2006. Biological control of Fusarium graminearum on wheat by antagonistic bacteria. Songklanakarin Journal of Science Technology 28: 29-38.

Patel, H.A., Patel, R.K., Khristi, S.K., Parikh, K., Rajendran, G., 2012. Isolation and characterization of bacterial endophytes from Lycopersicon esculentum plant and their plant growth promoting characteristics. Nepal Journal of Biotechnology 2(1): 37-52.

Qiu, M., Zhang, R., Xue, C., Zhang, S., Li, S., Zhang, L., Shen, Q., 2012. Application of bio-organic fertilizer can control Fusarium wilt of cucumber plants by regulating microbial community of rhizosphere soil. Biology and Fertility of Soils 48(7): 807-816.

Ramyabharathi, S.A., Raguchander, T., 2014. Efficacy of secondary metabolites produced by Bacillus subtilis EPCO16 against tomato wilt pathogen Fusarium oxysporum f. sp. lycopersici. Journal of Mycology and Plant Pathology 44(2): 148-153.

Santoyo, G., Moreno-Hagelsieb, G., Orozco-Mosqueda, M.D.C., 2016. Plant growth-promoting bacteria endophytes. Microbiological Research 183: 92-99.

Sharma, V.K., Nowak, J., 1998. Enhancement of verticillium wilt resistance in tomato transplants by in vitro co-culture of seedlings with a plant growth promoting rhizobacterium (Pseudomonas sp. strain PsJN). Canadian Journal of Microbiology 44(6): 528-536.

Shekhar, N., Bhattacharya, D., Kumar, D., Gupta, R.K., 2006. Biocontrol of wood-rotting fungi with Streptomyces violaceusniger XL-2. Canadian Journal of Microbiology 52(9): 805-808.

Smith, G.E., 1957. Inhibition of Fusarium oxysporum f. sp. lycopersici by a species of Micromonospora isolated from tomato. Phytopathology 47: 429-432.

Sreevidya, M., Gopalkrishnan, S., 2016. Penicillium citrinum VF1-51 as biocontrol agent to control charcoal rot of Sorghum (Sorghum bicolor (L.) Moench). African Journal of Micobiology Research 10(19): 669-674.

Sreevidya, M., Gopalkrishnan, S., Kudapa, H., Varshney, R.K., 2016. Exploring plat growth-promotion actinomycetes from vermicompost and rhizosphere soil for yield enhancement in chickpea. Brazilian Journal of Microbiology 47(1): 85-95. 
Swarupa, V., Pavitra, K., Shivashankara, K.S., Ravishankar, K.V., 2016. Omics-driven approaches in plant-microbe interaction. In: Microbial inoculants in sustainable agricultural productivity: Research perspectives, Singh, D.P., Singh, H.B., Prabha, R., (Eds.). Springer India,pp. 61-84.

Syngenta, 2015. Tomato Sahel: Crops \& Products. Available at [Access date : 01.10.2018]: http://www3.syngenta.com/country/es/sp/productos/Documents/ft/ft-tomate-sahel.pdf.

Trejo-Estrada, S.R., Sepulveda, I., Crawford, D.L., 1998. In vitro and in vivo antagonism of Streptomyces violaceusniger YCED9 against fungal pathogens of turfgrass. World Journal of Microbiology and Biotechnology 14(6): 865-872.

Vijayabharathi, R., Sathya, A., Gopalakrishnan, S., 2016. A renaissance in plant growth-promoting and biocontrol agents by endophytes. In: Microbial inoculants in sustainable agricultural productivity: Research perspectives, Singh, D.P., Singh, H.B., Prabha, R. (Eds.). Springer India. pp.37-60.

Yang, C., Crowley, D.E., Menge, J.A., 2001. 16S rDNA fingerprinting of rhizosphere bacterial communities associated with healthy and Phytophthora infected avocado roots. FEMS Microbial Ecology 35(2):129-136.

Ypadhyay, R.S., Rai, B., 1987. Studies on antagonism betweenFusarium udum Butler and root region microflora of pigeon-pea. Plant and Soil 101(1): 79-93.

Zeilinager, S., Gupta, V.K., Dahms, T.E.S., Silva, R.N., Singh, H.B., Ypadhyay, R.S., Gomes, E.V., Tsui, C.K.M., Chandra, S., 2016. Friends or foes? Emerging insights from fungal interactions with plants. FEMS Microbiology Reviews 40(2): 182-207.

Zhang, S., Raza, W., Yang, X., Hu, J., Huang, Q., Xu, Y., Liu, X., Ran, W., Shen, Q., 2008. Control of Fusarium wilt disease of cucumber plants with the application of a bioorganic fertilizer. Biology and Fertility of Soils 44: 1073-1080. 